10. Tokareva, N. M. and Shamne, A.V. (2017), Vikova ta pedahohichna psykholohiya: navch. posibnyk [Age and pedagogical psychology: teach. manual], Kyiv, Ukraine.

11. Chebotar'ova, O.V. (2012), Kompleks prohramno-metodychnoho zabezpechennya «Zmist korektsiyno-spryamovanoho navchannya i vykhovannya ditey $u$ spetsial'nykh doshkil'nykh zakladakh» (prohrama $z$ trudovoho vykhovannya, metodychni rekomendatsiyi, dydaktychni materialy)[Complex of program-methodical support "The content of correctional-directed education and upbringing of children in special preschool institutions" (program on labor education, methodical recommendations, didactic materials)], Poligrand, Kyiv, Ukraine. 
Олексенко Олександр Михайлович, магістр психології, фахівець кафедри медичної психології, ПрАТ «ВНЗ «МАУП»; 02000, вул. Фрометівська, 2, м. Київ, Україна; <psilogist89@gmail.com>; +38 (050) 659-47-96.

ORCID: https://orcid.org/0000-0002-3425-0580

\title{
АНАЛІЗ НАЙВПЛИВОВІШИХ НАПРЯМІВ ЕКЗИСТЕНЦІАЛЬНОЇ ПСИХОЛОГІї СУЧАСНОСТІ
}

\author{
Анотація \\ Ключові слова: екзистенціальна психологія, екзистенціальна
} психотерапія, екзистенціалізм.

Постановка проблеми. В умовах соціально-політичної нестабільності та європейського напряму розвитку України, є дуже важливим впровадження нових методів психотерапевтичної практики для подолання особистісних криз та інших фрустраційних станів.Екзистенціальна психологія $є$ одним із напрямів гуманістичної психології, й чи не найкраще підходить для вирішення цієї задачі.

Аналіз останніх досліджень і публікацій. Основні наукові дослідження з означеної тематики представлені в працях С. Степанова, Р.Фрейджера, Летуновського В. В., Тихонравова Ю. В., КучинскогоМ.Г., Ялома I. та ін. Авторами визначені основні напрями розвитку екзистенціальної психології.

Формулювання мети статті. Мета - теоретично проаналізувати найвпливовіші напрями екзистенціальної психології.

Виклад основного матеріалу: Висвітлені особливості найвпливовіших течій та напрямів екзистенціальної психології. Теоретично проаналізовано психотерапевтичні методи в рамках цих напрямів. Визначена та узагальнена практична цінність використання методів екзистенціальної психотерапії 3 
пацієнтами (клієнтами) які мають фрустраційні психічні стани, втрату сенсу життя, тощо.

Висновки та перспективи подальших досліджень.Теоретичний аналіз найвпливовіших напрямів та течій екзистенціальної психології поглиблює розуміння психологом особистості клієнта (пацієнта) а також розширює погляди на деякі, досить важливі проблеми (наприклад проблеми сенсу життя, існування, тривоги, депресії, тощо). Використання методів екзистенціальної психотерапії дозволяють знизити рівень фрустрації, уникати різноманітних негативних станів а також розкривають особистісний потенціал клієнта (пацієнта). В подальшому будуть розроблені методи психотерапевтичної практики, які будуть поєднувати в собі екзистенціальну психологію та когнітивну психотерапію та дослідження їх ефективності.

\section{Аннотация}

Олексенко А. М., магистр психологии, специалист кафедрі медицинской психологии, ПрАТ «ВНЗ «МАУП»; г. Киев, Украина. Анализ наиболее влиятельных направлений экзистенциальной психологи современности.

Ключевые слова: экзистенциальная психология, экзистенциальная психотерапия, экзистенциализм.

Постановка проблемы. В условиях социально-политической нестабильности и европейского направления развития Украины, очень важно внедрять новые методы психотерапевтической практики для преодоления личностных кризисов и других фрустрационных состояний. Экзистенциальная психология является одним из направлений гуманистической психологии, и как нельзя лучше подходит для решения этой задачи.

Анализ последних исследований и публикаций. Основные научные исследования по указанной тематике представлены в трудах С. Степанова, Г. Фрейджер, Летуновского В. В., Тихонравова Ю. В., Кучинский М., Ялома И. 
и др. Авторами определены основные направления развития экзистенциальной психологии.

Формулировка цели статьи. Цель - теоретически проанализировать самые влиятельные направления экзистенциальной психологии.

Изложение основного материала: Освещены особенности самых влиятельных течений и направлений экзистенциальной психологии. Теоретически проанализированы психотерапевтические методы в рамках этих направлений. Определена и обобщенна практическая ценность использования методов экзистенциальной психотерапии с пациентами (клиентами), которые имеют фрустрационные психические состояния, потерю смысла жизни, и тому подобное.

Выводы и перспективы дальнейших исследований. Теоретический анализ самых влиятельных направлений и течений экзистенциальной психологии углубляет понимание психологом личности клиента (пациента), а также расширяет взгляды на некоторые, весьма важные проблемы (например, проблемы смысла жизни, существования, тревоги, депрессии и т.д.). Использование методов экзистенциальной психотерапии позволяют снизить уровень фрустрации, избежать различных негативных состояний а также раскрывают личностный потенциал клиента (пациента). В дальнейшем будут разработаны методы психотерапевтической практики, которые будут сочетать в себе экзистенциальную психологию и когнитивную психотерапию, а также будут проведены исследования их эффективности.

\section{Annotation}

Oleksenko O. M., Magister of Psychology, Specialist of the Medical Psychology Department, The Private Joint-Stock Company Higher Educational Institution Interregional Academy of Personnel Management; Kyiv, Ukraine. Analysis of the most influential areas of existential psychology of our time.

Key words: existential psychology, existential therapy, existentialism. 
Formulation of the problem. In conditions of socio-political instability and European direction of development of Ukraine, it is very important to introduce new methods of psychotherapeutic practice to overcome personal crises and other frustration conditions. Existential psychology is one of the areas of humanistic psychology, and is not best suited for solving this problem.

Analysis of recent research and publications. The basic scientific researches on the specified subjects are presented in the writings of S. Stepanov, R. Freider, V. Letunovsky, V. Tikhonravova, M. Kuchinsky, M. Yaloma and others. The authors identify the main directions of the development of existential psychology.

Wording of purpose. The purpose - to theoretically analyze the most influential directions of existential psychology.

Presentation of the main material: Features of the most influential currents and directions of existential psychology are highlighted. Theoretically analyzed psychotherapeutic methods within these directions. The practical value of using existential psychotherapy methods with patients (clients) with frustration mental states, loss of meaning of life, etc. is determined and generalized.

Conclusions and perspectives of further research. The theoretical analysis of the most influential directions and currents of existential psychology deepens the understanding by the psychologist of the client's personality (patient) and also broadens the views on some very important problems (eg, problems of meaning of life, existence, anxiety, depression, etc.). The use of existential psychotherapy methods can reduce the level of frustration, avoid various negative states, and also reveal the personal potential of the client (the patient). In the future, methods of psychotherapeutic practice will be developed, which will combine existential psychology and cognitive psychotherapy and study their effectiveness.

Ключові слова: екзистенціальна психологія, екзистенціальна психотерапія, екзистенціалізм. 
Постановка проблеми. Сучасні умови життя ставлять перед особистістю непрості завдання, вирішення яких супроводжується негативними психо-емоційними станами. Різноманітні події в житті людей, втрата близьких, хвороби, вікові кризи, тощо можуть викликати екзистенціальну фрустрацію. Для вирішення цих та інших проблем потрібно використовувати методи, які розробили екзистенціальна психологія та психотерапія. В цій статті викладений аналіз найважливіших течій екзистенціальної психотерапії.

Аналіз останніх досліджень. Екзистенціальна психологія (від лат. existentia - існування; гр. psyhē - душа+ гр. logos - слово, поняття, вчення) один із напрямів гуманістичної психології, що вивчає: 1) проблеми часу, життя і смерті; 2) проблеми свободи, відповідальності та вибору; 3 ) проблеми спілкування, любові і самотності; 4) проблеми смислу існування людини. Екзистенціальна психологія підкреслює унікальність особистого досвіду конкретної людини. Провідною ії метою є вирішення проблеми відновлення автентичності особистості - відповідності іï буття у світі іiі внутрішній природі. У практиці сучасної екзистенціальної психології використовуються досягнення психоаналізу. [1].

Екзистенціальна психологія зародилася в XX столітті на основі ідей екзистенціальної філософії. Основоположником по праву вважають данського релігійного мислителя СеренаК'єркегора (РоллоМей у своїй книзі «Сенс тривоги» спирається на філософію і психологію К'єркегора)[1, 2].

В наш час основними напрямками екзистенціальної психології та психотерапії вважаються:

- Екзистенціальний аналіз Людвіга Бінсвангера.

- Dasein-аналіз (дазайн-аналіз) Медарда Боса і Аліси Хольцхей-Кунц.

- Логотерапія Віктора Франкла.

- Екзистенціальний аналіз АльфрідаЛенглі.

- Екзистенціальне консультування Джеймса Бьюдженталя, ІрвінаЯлом, РоллоМея. 


\section{Виклад основного матеріалу.}

Екзистенціальна психологія Людвіга Бінсвангера. Людвіг Бінсвангер - швейцарський психіатр i філософ. Бінсвангер, спираючись на екзистенціальну аналітику (Daseinsanalytik), створив власне філософськоантропологічне і психіатричне вчення, назване «екзистенційним аналізом» (Daseinsanalyse). Бінсвангервніс зміни в психоаналітичну метапсихологію і в практику психотерапії, відкинувши біологізм і детермінізм в трактуванні несвідомих процесів. Людське існування розуміється Бінсвангером як єдність трьох тимчасових модусів - минулого, сьогодення і майбутнього. Неврози і психози є осмисленими способами трансцендувания, конституювання світу i самої екзистенції. Симптоми різних психічних розладів виникають у зв'язку з обмеженістю горизонту бачення: один часовий модус стає домінуючим, що перешкоджає справжньому існуванню людини і може вести до психічного захворювання. Клінічна психіатрія і психоаналіз дають нам поверхневий опис симптомів і синдромів, ігноруючи індивідуальне «буття-в-світі». Психопатологія має своїм джерелом особливості будови «життєвого світу» пацієнта. Цей «життєвий світ» конституюється актами свідомості, проте у психотика він $є$ не менш осмисленим, ніж у терапевта. Не існує реальності яка $є$ для всіх однаковою і «нормальною», яку можна вважати чимось само собою зрозумілим і протиставляти «безумству». Відхилення від того, що вважається «нормою», означає створення нової «норми». Для всіх «світів», утворених маніакальним свідомістю, властива своя особлива «норма». Неврози і психози - суть модифікації фундаментальних структур буття-всвіті, способів трансцендування. Описувані психоаналізом невротичні симптоми обумовлені не травмами, дитячими фіксаціями й ідентифікаціями, а специфічною «конфігурацією» екзистенції, пануванням одного 3 модусів тимчасового трансцендування. В результаті звуження горизонту бачення відбуваються порушення в «смисловий матриці», інші модуси перестають розглядатися як можливість існування. Бінсвангер зберігає основні елементи психоаналітичної терапії, але переглядає основні поняття психоаналізу, в 
першу чергу поняття несвідомого психічного. У феноменологічної психіатрії Бінсвангера несвідоме являє собою результат вузькості обрію екзистенції, втечі від власних творчих можливостей в невроз. Переглядається i фрейдівське тлумачення сновидінь. Інтерпретації підлягає не гіпотетичне «приховане», але саме «явне» зміст сновидіння - за ним не приховується якийсь витіснений в несвідоме зміст[3].

У 1930-1940 рр. Бінсвангер розвиває власну філософську антропологію, яка все більше розходиться з Daseinsanalytik Гайдеггера. В роботі «Основні форми і пізнання людського існування» (Grund formenund Erkenntnis desmens chlichen Daseins, Zurich, 1942), Бінсвангер з погляду персоналістської позицій критикує Гайдеггера: крім світу «турботи», «занедбаності», що характеризується Бінсвангером як світ взаємного опредметнювання (dasNehmen-bei- Etwas - «прийняття-за-щось»), інструментальної корисності, $\epsilon$ модус «буття-один-з-іншому», в якому Я і Ти нероздільні. У цьому модусі «Ми» (dieWirheit) або «любов» інакше структуровані простір і час. У 19501960-е Бінсвангер пише ряд монографій, в яких з позицій феноменологічної психіатрії здійснюється опис різних психічних захворювань (Drei Formen miss gluckten Daseins, Tubingen, 1956; Schizofrenie, Pfullingen, 1957; Wahn, Pfullingen, 1965 і ін.). Роботи Бінсвангера мали значний вплив на екзистенційну феноменологію і «екзистенціальний психоаналіз». Разом 3 тим, його трактування Гайдеггера в дусі філософської антропології викликала негативну реакцію самого Гайдеггера і різку критику з боку М. Босса і інших прихильників «онтологічної» інтерпретації Daseinsanalytik[3].

Дазайн-Аналіз. Дазайн (нім. Dasein [da:zaIn]) - філософське поняття, яке використовується Мартіном Гайдеггером в його відомій праці «Буття і час» і в інших його роботах. Дазайн-аналіз практикується в ряді країн, кожна 3 яких має національну асоціацію, яка здійснює навчання і супервізію практикуючих фахівців. Міжнародна федерація дазайн-аналізу (IFDA), яка афілійована Європейською асоціацією психотерапії, об'єднує національні асоціації. Наразі президентом IFDA $є$ Адо Хейген (AdoHuygens), віце- 
президент і секретар - Йозеф Йеневайн (JosefJenewein). ЖіонКондрау, досліджуючи поняття Дазайн (Dasein) для психотерапії, пише, відсилаючи до Гайдеггера: «Людина $\epsilon$ «тут» як просвіт буття: тому Дазайн було вибрано Гайдеггером як чистий буттєвий образ цього сущого.»Це суще, яке є нами самими та яке серед іншого має буттєву можливість запитування, ми термінологічно схоплюємо як Dasein. Якщо, таким чином, мова йде про Дазайн, то завжди мається на увазі конкретна людина[4].

Dasein-aналіз Meдарда Босса. Медард Бос (нім. Medard Boss, 4 жовтня 1903 році, Санкт-Галлен - 21 грудня 1990, Цолліконе) - швейцарський психіатр і психолог, один 3 відомих представників екзистенціальної психотерапії.

Dasein як світло Буття. Аналогія зі світлом грає найважливішу роль в концепції Босса. Сам феномен світу як такий - означає «висвітлюватися», виходити на світло з темряви ( «приховування» у Гайдеггера). Босс розуміє Dasein як «що висвічує», що виводить речі «на світло». Метафора світла і висвічування визначає і розуміння Боссом таких речей як психопатологія, психологічний захист, терапевтичний стиль, інтерпретація сновидінь. Захист по Боссу є «невисвічння» окремих аспектів життя, а психопатологія (як стан людини) подібна вибору життя в темряві. Терапія повертає людей до їх базової світлості і відкритості. «Ми можемо назвати цей процес висвітлення» (Boss, 1962)[5].

Вслід за Гайдеггером, Босс не втомлюється підкреслювати, що всі ми живемо не в ізольованому, а в спільному світі (екзістенціал буття-разом). Зустрічаючись, ми висвічуємо один одного, дозволяємо один одному бути як людським істотам. Людська екзистенція є розділена (спільна) екзистенція.

Dasein-аналіз Медарда Босса пропонує пацієнтові «відпустити речі» (Gelassenheit), дозволити їм бути такими, якими вони є. Найчастіше ми тримаємо занадто напруженим наше життя, намагаючись тримати все під контролем, але життя - це «завжди занадто багато для нас». Ми повинні трохи більше довіряти життю, довіряти долі. Босс говорить про те, що нам 
слід «стрибнути в воду», замість того, щоб весь час пробувати, чи не занадто вона холодна; замість того, щоб утримувати світло Dasein у вузькому фіксованому пучку, нам слід дозволити світу виливатися вільно. Наступний важливий момент - це пояснення природи нашого розуміння. Через спалах світла в темряві ми починаємо бачити те, чого раніше не бачили. Важливо зрозуміти, що це не процес накопичення інформації, а деякий інсайт, що дозволяє схопити всю ситуацію в цілому i тим самим іiі зрозуміти. Висвітлення у Босса дуже тісно пов’язане 3 відкритістю. Чим більша відкритість, тим яскравіше світло. Для наочності ми також можемо скористатися метафорою вікна. Вікна невротиків вузькі і тьмяні, вікна психотиков - зовсім маленькі дірочки, які ледь пропускають промінь світла. Так ось, цей спалах (інсайт, осяяння) дозволяє світлу прорватися через всі перепони і висвітлити речі з темряви, тільки в цьому випадку ми здатні ці речі зрозуміти або усвідомити, точніше буде сказати - зрозуміти значення цих речей, їх зміст[5].

Важливо знати, що «розуміння» в даному випадку не $є$ просто когнітивним процесом. Іноді ми говоримо: «Він мене розуміє», або «Вона мене розуміє», - маючи на увазі щось більш складне і глибоке, ніж просто когнітивний процес розуміння значення слів: «Я живу з ним тому, що він мене розуміє ...» Що в це разі означає «розуміти»? Як можна зрозуміти людину? Яким чином? Босс відповідає на це питання так: «Зрозуміти означає дозволити іншій людині бути у відповідністі з його внутрішніми потенціями, смислами, його сутністю». Таким чином, висвітлити - це і є зрозуміти, лише розуміння це відноситься не тільки до однієї людини, а до всіх речей у світі. Саме в цьому полягає сутність висвітлювання як інсайту[5].

Босс не втомлюється повторювати, що відкритість людини не є одне 3 його численних властивостей, в той же - час, це і не властивість простору. Сама людська сутність - це фундаментальна відкритість, - можливість осягнути щось як щось. Відкритість завжди потрібна для того, щоб зустріти речі такими, якими вони є, а не для чого-яких ще. «Якщо це не так, то як 
взагалі щось може з'являтися в полі зору людини в своєму значенні?» ставив питання Босс. Ще один момент, дуже важливий з точки зору Боса, це те, що людська відкритість не пасивна «подібно порожній кімнаті, куди вносять меблі». Людська відкритість передбачає відповідальність у сенсі відповіді речам в їх особливих шляхах, а також в сенсі вибору свого власного ставлення до речей. «Відкритість людської екзистенції складається 3 можливості осягнути присутність і значення того, що зустрічається, а також 3 можливості відповіді феноменам, способам, що відповідають їх значенню» [6].

Для того щоб краще зрозуміти ідею відкритості Босса, очевидно, варто почати зі світу. Бос вважає, що особистість можливо зрозуміти тільки як «людину в світі» (буття-в-світі). Якщо розглядати людину як деяку замкнуту свідомість, відділену від світу явищ, в якому вона існує, - зрозуміти їі неможливо. У цьому сенсі відкритість розуміється як здатність до деякої взаємодії, що розвиває і збагачує людський організм і його особистість. Д.Леонтьев ілюструючи ідею відкритості Босса - приводить метафору обміну речовин. Організм може рости, тільки обмінюючись речовинами 3 навколишнім середовищем. Якщо такого обміну не буде, якщо організм заблокує обмін речовин, то він почне гнити. Коли обмін речовин припиняється, починається гниття.

Для Босса відкритість - це досить широке поняття, але, перш за все, це відкритість світу для взаємодії з ним. Відкритість - головна характеристика самої людської екзистенцї. Стосовно до феноменологічного аналізу це означає, що найкраща теоретична орієнтація, яку може прийняти феноменологія, - це відмова від будь-якої теоретичної орієнтації. Щоб зрозуміти те, з чим він стикається, потрібно відмовитися від будь-яких апріорних схем, інтерпретацій i заданих принципів, дати феноменам говорити самим за себе. Головний принцип Dasein аналізу - це дати тому, що ми бачимо, з'явитися в своєму власному значенні, і у відповідність з цим 
унікальним для кожного феномена значенням поставитися до нього, відповісти на його заклик [6].

Значення можливостей в Dasein аналізі. Можливість в розумінні Боса значно відрізняється від традиційного розуміння можливості. Якщо традиційний підхід до поняття можливості, що йде ще від Арістотеля, i, досяг кульмінації в теорії Маслоу, який розуміє можливість як деяку закладену в нас потенцію, то для Боса можливість - це реальність, яка щуе не здійснена. Вона реальна не менше ніж все інше. Можливості знаходяться не всередині нас і не поза нами, вони закладені в самій структурі нашого існування, в світі. I ми маємо здатність ці можливості втілювати в життя. Сама людська екзистенція, по Боссові, існує як ансамбль можливостей. Ми самі існуємо як можливості того чи іншого ставлення до світу. Як людські істоти ми не тільки маємо можливості висвічувати речі у світ, але також маємо можливість вибирати тип відносин, в яких ці речі можуть бути висвітлені. А це означає можливість вибору, як ставитися до тих речей, які нам зустрічаються. Дуже важливою є наша відповідальність за те що ми робимо кінцевий вибір єдиної можливості 3 багатьох та іiі втілюємо. Поняття можливості, по Босові, тісно пов'язане з ідеєю свободи людини. Ступінь свободи, якою володіє людина, істотно більше, ніж ступінь свободи, якою володіють інші істоти, тому що люди здатні розуміти буття, тобто здатні бачити можливості. Однак не всі можливості можна бачити одночасно, не всі можливості можуть бути здійснені одночасно. Якісь можливості ми вирішуємо здійснити зараз, якісь відкладаємо на завтра, від деяких відмовляємося взагалі. I кожен з нас безпосередньо відповідає за вибір своїх можливостей. Ця відповідальність лежить на нас завжди, в кожен момент часу, незалежно від того, хочемо ми цього чи не хочемо. Відповідно Боссу, нездійснені можливості не менше реальні, ніж ті, які здійснені. Тому, по Босові, говорити про актуалізацію можливостей неправомірно[5].

Значення свободи в Dasein-аналізі. Босс стверджує, що для того, щоб мати можливість вибору, що власне і становить суть індивідуальної свободи, 
потрібна можливість цієї можливості, свого роду пре- або до -свобода, яка є основою нашої індивідуальної свободи - наша фундаментальна відкритість (висвітлення). Існує два можливих виборів як проявів людської свободи: 3 якою річчю мати справу, і яким чином з нею мати справу. Звичайно, людська свобода, як і все людське, не абсолютна. Проте, не варто забувати, що навіть обмежена свобода - все одно форма свободи [7].

Мету терапії Босс бачить, подібно Фрейду, в тому, щоб звільнити людину від обмежень невротичної несвободи. Виникає доречне запитання, яким чином Dasein спочатку вільне і відкрите, приходить до свого існування в якості невротично обмеженого і поневоленого? Босс відповідає на це питання наступним чином: «Люди дійсно народжуються вільними і відкритими. Однак $з$ народження вони під впливом «не можна» і «роби як я» втрачають свою початкову свободу». У зв'язку з цим Босс згадує фрейдівське супер-его і гайдеггеровскоedasMan. Однак все перераховане вище є лише одним із шляхів, через який початкова свобода і відкритість можуть бути втрачені, ще можуть бути хвороби і нещасні випадки [7].

Все ж цими обмеженнями неможливо «обмежити» справжню природу Dasein. Отже, мета терапії - повернути людині його початкову свободу i відкритість. Хвороба - не що інше, як блокування цієї початкової відкритості та свободи Dasein, що означає неможливість жити, реалізуючи ті потенції, які найкраще можуть бути нами реалізовані. Ми говоримо про те, що вільна людина здорова, оскільки вона вільна від початку. Повертаючи людину до свободи, ми повертаємо його до власної початкової відкритості природі, а значить і до здоров'я. Чим глибше «рана» (ступінь придбаної несвободи), тим серйознішою і тривалої повинна бути робота терапевта по звільненню [7].

Екзистенціальна психологія Ролло Мея. Ролло Ріс Мей (21 квітня, 1909 - 22 жовтня, 1994) - відомий американський психолог і психотерапевт, теоретик екзистенціальної психології. У своїх творах піддає ретельному аналізу основні проблеми людської екзистенції: добро і зло, свобода, відповідальність і доля, творчість, вина i тривога, любов i насильство. 
Найбільш відома робота Мея «Любов і воля» (англ. LoveandWill) стала американським національним бестселером і отримала в 1970 році премію РальфаУолдо Емерсона за ерудицію в області наук про людину.РоллоМея, безперечно, можна назвати однією 3 ключових фігур не тільки американської, а й світової психології. До самої своєї смерті він був одним 3 провідних екзистенціальних психологів в США. За роки роботи в якості психотерапевта, Мей розробив нову концепцію людини. Його підхід спирався більшою мірою на клінічні експерименти, ніж на кабінетну теорію. Людина, з точки зору Мея, живе сьогоденням, для нього актуально в першу чергу те, що відбувається тут і зараз. У цій єдиній, справжній реальності людина формує себе сама, на неї покладається відповідальність за те, ким вона в кінцевому рахунку становиться. Проникливі здогади про природу людського існування, які отримують переконливе підтвердження в ході подальшого аналізу, сприяли популярності Мея не тільки серед професійних психологів, а й серед широкої публіки. Роботи Мея відрізняються простотою і глибиною основних положень, які культивують здоровий прагматизм i раціональність в поведінці конкретного індивіда [8].

Замислюючись над корінними відмінностями між психічно-здоровою, повноцінною людиною і хворим, Мей прийшов до наступних висновків. Багатьом людям, вважав він, бракує хоробрості зустрітися віч-на-віч зі своєю долею. Спроби уникнути подібного зіткнення призводять до того, що вони жертвують більшою частиною своєї свободи і намагаються піти від відповідальності, заявляючи про споконвічну несвободу своїх дій. Щоб не робити вибір, вони втрачають здатність бачити себе такими, якими вони $є$ насправді, і переймаються почуттям власної меншовартості і відчуженості від світу. Здорові ж люди, навпаки, кидають виклик своїй долі, цінують і оберігають свою свободу i живуть справжнім життям, чесною по відношенню до себе та інших. Вони усвідомлюють неминучість смерті, але їм вистачає сміливості жити в сьогоденні [8]. 
На відміну від Фрейда, Адлера, Роджерса та інших теоретиків особистості, які спиралися на багатий клінічний досвід, Мей не заснував школу з безліччю гарячих послідовників і своїми методами. Проте він дуже багато писав про предмет психотерапії. Мей вважав, що неправильно орієнтувати психотерапію на лікування пацієнта від конкретної хвороби або на рішення його конкретної проблеми. Замість цього він ставив перед терапією завдання зробити людей більш людяними, допомогти їм розширити і розвинути свою свідомість, підштовхнувши їх тим самим до можливості вільного вибору. Можливість вибору, в свою чергу, веде до зростання свободи і одночасно відповідальності.

Мей стверджував, що «мета психотерапії - зробити людей вільними». «Я вважаю, - писав він, - що робота психотерапевта повинна полягати в тому, щоб допомогти людям отримати свободу для усвідомлення і здійснення своїх можливостей». Мей наполягав на тому, що терапевт, який зосереджується на симптомах пацієнта, випускає з уваги щось важливіше. Невротичні симптоми є всього лише способами втекти від своєї свободи і показниками того, що пацієнт не використовує свої можливості. Коли пацієнт стає більш вільним і людяним, його невротичні симптоми, як правило, зникають, невротична тривога поступається місцем нормальної тривозі і невротичне відчуття провини замінюється нормальним почуттям провини. Але все це - побічні вигоди, а не головна мета терапії. Мей твердо дотримувався думки, що психотерапія повинна в першу чергу допомагати людям відчути своє існування і що «будь-яка наступна одужання від симптомів повинно бути вторичним продуктом цього процесу» [9].

Логотерапія В. Франкла. Ві́ктор Емі́ль Франкл (нім. Viktor Emil Frank1; 26 березня 1905, Відень, Австро-Угорщина - 2 вересня 1997, Відень, Австрія) - австрійський психіатр, психотерапевт і філософ єврейського походження, творець так званої Третьої Віденської Школи психотерапії. Згідно Франклу, йоготерапія грунтується на трьох поняттях: свободі волі, волі до сенсу і сенсу життя [10]. Концепція логотерапії стверджує, що 
рушійною силою людської поведінки є прагнення знайти i реалізувати існуючий в зовнішньому світі сенс життя. Однією 3 ключових людських властивостей, на думку Франкла, є воля до сенсу, яку Франкл протиставив адлеріанському прагненню до переваги, самоствердження, спрямованому на компенсацію комплексу неповноцінності i фрейдівському принципу задоволення.

Стан людини з фрустрованим прагненням до сенсу, на думку Франкла, i називається екзистенціальним вакуумом, про який писали філософиекзистенціалісти. Екзистенціальний вакуум, згідно логотерапії, може призвести до ноогенного неврозу (неврозу, який виникає внаслідок фрустрації прагнення до сенсу), клінічній симптоматиці[11].

3 точки зору Франкла, сенс не є щось суто суб’єктивне, - людина не вигадує його, а знаходить у навколишньому світі. Франкл називає три шляхи, йдучи за якими людина може зробити своє життя осмисленим [12]:

- Творчість;

- Отримання нового досвіду, переживання, або зустріч 3 кимось на життєвому шляху;

- Знаходження сенсу в житті, в тому числі в стражданнях. Методи логотерапії:

- Логоаналіз - його розробив американець Джеймс Крамбо, один з учнів Віктора Франкла. Метод дозволяє провести детальну, як виражається Крамбо, інвентаризацію життя пацієнта. В логоаналізі використовуються два основні прийоми: розширення поля свідомості і стимулювання творчої уяви.

- Парадоксальна інтенція. Для лікування фобій i обсесивнокомпульсивного розладу Франкл запропонував метод парадоксальної інтенції. В рамках даної методики пацієнту, що має, наприклад, певну фобію, пропонується парадоксальна спроба захотіти то, чого він найбільше боїться. Це може бути об'єкт, дія або ситуація, в якій пацієнт дуже боїться опинитися.

- Дерефлексія. Суть методу дерефлексії в тому, щоб подолати нав'язливу схильність до самоспостереження, яке стає надмірним. Людині 
рекомендується переключити увагу з самого себе на смисли і цінності, які він може втілити в навколишньому світі. Сам Франкл так охарактеризував дерефлексію: «За допомогою дерефлексії пацієнт отримує можливість ігнорувати свій невроз, фокусуючи свою увагу на чомусь сторонньому. Він направляє свою увагу на життя, повну потенційних смислів і цінностей, які мають безпосереднє відношення до його особистих здібностей.»

Екзистенціальний аналіз. А. Ленге. АльфрідЛенгле (нім. AlfriedLängle; рід. 27 березня 1951 Гьотцис) - австрійський психолог, психотерапевт. На основі логотерапіїталогоаналізу розробив новий напрям в психотерапії, що отримав назву екзистенціальний аналіз[14].

Ленгле говорить про екзистенціальний аналіз, як про окремий психотерапевтичний метод, який, на відміну від логотерапіїФранкла, розглядається саме як самостійна терапія, а не просто як доповнення до традиційної психотерапії. В цьому сенсі, логотерапія $\epsilon$ частиною екзистенціального аналізу. Сила йоготерапії, на думку Ленгле, полягає в тому, що вона допомагає людям впоратися 3 важкими, невід'ємними життєвими ситуаціями такими як невиліковні хвороби, втрати близьких. Основна сфера застосування логотерапії - профілактична робота, виховання i соціальна робота. Ленгле прямо заявляє про те, що саме екзистенційний аналіз використовується як психотерапевтичний інструмент, а логотерапіязастосовується головним чином при консультуванні та профілактичній роботі [13].

Екзистенція для Ленгле є «наповнення змістом, яке втілюється вільно і відповідальнов життя та в створюваний самою людиною світ, 3 яким вона перебуває у відносинах взаємовпливу / взаємодії і протиборстві» (Ленглі, 1999). На думку Ленгле екзистенціальний вимір життя людини недооцінюється іншими психотерапевтичними школами[13].

Мета екзистенціального аналізу як психотерапії по Ленгле є досягнення афірмації з життям, тобто особливого роду згоди зі своїм життям (тобто згоди-підтвердження, згоди-співучасті). Оскільки життя завжди відбувається 
тільки в теперішньому часі, вихідним пунктом екзистенціального аналізу є «актуальне». Однак в центрі аналізу перебуває майбутнє як творення подальшому житті. Якщо людина не бачить майбутнього його екзистенція заблокована. Екзистенціальному аналітику важливо зрозуміти через що це відбувається. Слідом за ФранкломЛенгле виділяє три основні причини таких блокувань[13]:

- Тягар минулого заступає справжне. На відміну від психоаналізу Фрейда, який за словами Ленгле проводить тотальне «прочісування минулого», екзистенціальний аналіз зосереджує свою увагу тільки на тих моментах минулого, які роблять свій деструктивний вплив на сьогодення.

- Невірні установки людини по відноменню до самого себе $i$ погане знання своїх можливостей. В цьому випадку екзистенціальний аналіз здійснює послідовне опрацювання відносин, установок і намірів пацієнтів. Центральними питаннями при цьому стають «Чи можу я довіряти власним почуттям?» І «Як я можу дізнатися, чого я хочу?»

- Екзистенціальний вакуум. «У людей є все для того щоб жити, але у них немає того заради, чого жити». Екзистенціальний аналіз в цьому випадку використовує методи логотерапіїФранкла для того, щоб допомогти людині знайти сенс власного існування.

Ірвін Девід Ялом - американський психіатр і психотерапевт, доктор медицини, професор психіатрії Стенфордського університету; відомий як автор науково-популярної та художньої літератури[17]». Ірвін Ялом $є$ послідовним противником де-індивідуалізованого, бюрократичного, формального підходу в психотерапії. Особливо різко виступав проти (як він сам називав) «короткострокової діагноз-орієнтованої терапії». «Короткострокова діагноз-орієнтована терапія», по Ялому, управляється економічними силами, грунтується на вузьких, формальних діагнозах, одностороння, керована протоколом, «терапія для всіх», без урахування індивідуальності. Ялом вважає, насамперед, що для кожного пацієнта потрібно«винаходити» нову психотерапію, бо у кожного є унікальна історія. 
Основою цієї «нової» терапії служить терапія, побудована на міжособистісних взаєминах «тут і зараз» пацієнта i психотерапевта, на взаємних одкровеннях[16]». Не останню роль на формування його поглядів вплинув й психоаналіз. У своїх роботах Ялом пройшов шлях від психоаналізу до екзістенціально-гуманістичного терапевта. Велике місце в його працях ( «Мамуся i сенс життя», «Брехун на кушетці», «Дар психотерапії») відводиться подолання екзистенціальному страху смерті. У творі «Вдивляючись в сонце. Життя без страху смерті »(2008) він підводить підсумок вивчення цієї проблеми, і пише:« Як тільки ми опиняємося здатними протистояти факту своєї власної смертності, ми можемо перебудувати наші пріоритети, спілкуватися більш глибоко з тими, кого ми любимо, цінуємо більш гостро красу життя і збільшуємо свою готовність взяти на себе ризики, необхідні для особистого виконання[15].»

Висновки та перспективи подальших досліджень.В даній статті ми провели теоретичний аналізнайвпливовіших течій та напрямів сучасної екзистенціальної психології та психотерапії. Зокрема, описані такі автори, як Бінсвангер Людвіг та МедардБосс, - основоположники Дазайн-аналізу психології «тут-буття», - одного з перспективних напрямів екзистенціальної психотерапії. Важливі досягнення у вивченні таких феноменів як свобода, любов, сенс життя, тривога, тощо має відомий екзистенціальний психолог РолоМей. Коротко були розглянуті особливості логотерапії - практичного напряму, створеного Віктором Емілем Франклом, який поєднує в собі три важливих методи екзистенціальної психотерапії - логоаналізу, парадоксальної інтенції та дерефлексії. Не менш важливими є аналіз таких сучасних послідовників гуманістичної та екзистенціальної психології як Ірвін Ялом та Альфрід Ленге.

Вивчення принципів сучасної екзистенціальної психології та їх поєднання з методами когнітивної психології й когнітивно-поведінкового підходу є перспективними, оскільки вони можуть бути використані при терапії різноманітних небажаних психологічних станів (фрустрації, 
вигорання, екзистенціальна криза, депресій, тощо), та деяких психічних хвороб.

\section{Список використаних джерел}

1. Existential therapy: An introduction [Електронний ресурс].- режим доступу: http://www.academia.edu/7150933/EXISTENTIAL_THERAPY_intro

2. Мей Р. Зміст тривоги (англ. TheMeaningofAnxiety) / Р. Мей [пер. 3 англ. М. І. Завалової, А. Ю. Сибуріної].- К.: PSYLIB, 2005.-384 с.

3. Бінсвангер Л. Буття-в-світі / Л. Бінсвангер.- М.:Вид-во КСП+Ювента, Ленато.- 1999.- 300 с.

4. Condrau, G. (1985). Philosophische und anthropologische Grundlagen der Daseinsanalyse. Daseinsanalyse, 189-296 / Кондрау Ж. Філософські та антропологічні основи дазайн-аналізу // Дазайн-аналіз: офіційний журнал міжнародної дизайн-аналітичної асоціації.- 1985.- №2.- с. 189-296 [пер. І. Казакова] [Електронний ресурс].- режим доступу: https://cyberleninka.ru/article/n/predislovie-k-publikatsii-perevoda-stati-zhionakondrau-filosofskie-i-antropologicheskie-osnovaniya-dazayn-analiza.

5. Летуновський В. В. Порівняльний аналіз методологічних основ варіантів екзистенціального аналізу Л. Бінсвангера та М. Босса / В. В. Летуновський // Розуміння як фактор особистісного розвитку.- Кемерово: Графіка, 2002.- [Електронний ресурс].- режим доступу: http://hpsy.ru/public/x026.htm.

6. Летуновський В. В. До 100-річчя з дня народження Медарда Босса / В. В. Летуновський // [Електронний ресурс].- режим доступу: http://hpsy.ru/public/x748.htm.

7. Кучинський М. Г. Розвиток феноменологічного методу та Dasein-аналіз / М. Г. Кучинський // Dasein-аналіз ву філософії та психології.- 2011.- С. 94169.

8. Фрейджер Р. Теорії особистості та особистісне зростання / P. Фрейджер, Дж. Фейдімен .- [Електронний ресурс].- режим доступу: https://www.gumer.info/bibliotek_Buks/Psihol/freydjer/index.php. 
9. May R. Psychology and the human dilemma / R. May // Gendlin, E.T. (1967, June). [Review of the book Psychology and the human dilemma]. Psychology Today, 11-12. From http://www.focusing.org/ gendlin/docs/gol_2122.html

10. Франкл В. Теорія і терапія неврозів / В Франкл.- М.: Біг-Пресс, 2012.$224 \mathrm{c}$.

11. Романін А. М. Основи психотерапії / А. М. Романін.- М.: КНОРУС, 2006.- 469 c.

12. Франкл В. Людина в пошуках справжнього сенсу. Психолог у концтаборі / В. Франкл [пер. О. Замойська].- К.: Вид-во «Книжковий клуб «Клуб сімейного дозвілля».- 2016.- 160 с.

13. Ленгле А. Психотерапія - науковий метод чи духовна практика? Про співвідношення між іманентним та трансцендентним на прикладі екзистенціального аналізу / А. Ленгле // «Московський психотерапевтичний журнал».- 2003.- № 2.

14. Есельсон С. Б. Екзистенціалізм у психології / Есельсон С. Б., Летуновський В. В. // Екзистенціальна традиція: філософія., психологія, психотерапія [Електронний ресурс].- режим доступу: http://hpsy.ru/public/x2711.htm.

15. Yalom Irvin D. Staring at the Sun: Overcoming the Terror of Death / Irving D. Yalom // JOSSEY-BASS A Wiley Imprint.- 2008.- 317 p.

16. Скарлош С. Як навчитися любити. Ірвін Ялом про неврози, сенс життя, свою маму та Всевишнього / С. Скарлош // Російський Репортер.2012.- № 45 (274).

17. Yalom Irvin D. ExistentialPsychotherapy / Irvin D. Yalom.- Kindle, Aug.1, 2008.

\section{References}

1. Existential therapy: An introduction [Online], available at: http://www.academia.edu/7150933/EXISTENTIAL_THERAPY_intro 
2. May, R. [trans. from english Zavalova, M. I. Siburina, A. Yu.] (2005), Zmist tryvohy (anhl. The Meaning of Anxiety) [The Contents of the Anxiety (English The Meaning of Anxiety)], PSYLIB, Kyiv, Ukraine.

3. Binswanger, L. (1999), Being-in-the-world, View of PCB + Juventus, Lenato, Moscow, Russia.

4. Kondrau, J. (1985), Philosophical and anthropological foundations of the dazein analysis, Dazayn-analysis: the official journal of the international design and analytical association, vol.2, pp. 189-296 [Online], available at: https://cyberleninka.ru/article/n/predislovie-k-publikatsii-perevoda-stati-zhionakondrau-filosofskie-ianantropologicheskie-osnovaniya-dazayn-analiza.

5. Letunovsky, V.V. (2002), "Comparative analysis of methodological foundations of variants of existential analysis by L. Binswanger and M. Boss", Rozuminnya yak faktor osobystisnoho rozvytku,Kemerovo, Russia [Online], available at: http://hpsy.ru/public/x026.htm.

6. Letunovsky, V.V., Do 100-richchya $z$ dnya narodzhennya Medarda Bossa" [To the 100th anniversary of the birth of Medard Boss], [Online], available at: http://hpsy.ru/public/x748.htm.

7. Kuchinsky, M. G. (2011), “Development of the phenomenological method and Dasein-analysis", Dasein-analysis of philosophy and psychology, pp. 94-169.

8. Frederinger, R. Feidimen, J. “ Theories of Personality and Personal Growth" [Online], available at: https://www.gumer.info/bibliotek_Buks /Psihol/freydjer/index.php.

9. May, R. Gendlin, E.T. (1967), "Psychology and the human dilemma", Psychology Today, pp. 11-12, [Online], available at: http://www.focusing.org/ gendlin / docs / gol_2122.html

10. Frank1, B. (2012), Teoriya i terapiya nevroziv [Theory and Therapy of Neuroses], Big-Press, Moscow, Russia.

11. Romanin, A. M. (2006), Osnovy psykhoterapiyi [Fundamentals of Psychotherapy], KNOROUS, Moscow, Russia. 
12. Frank1, V. [trans. O. Zamoyskaya] (2016), Lyudyna v poshukakh spravzhn'oho sensu. Psykholoh u kontstabori [Man in search of true meaning. Psychologist at concentration camp], View of "Book Club" Family Leisure Club, Kyiv, Ukraine.

13. Langle, A. (2003), "Psychotherapy - a scientific method or spiritual practice? On the Relationship between Immanent and Transcendent on the Example of Existential Analysis", Moskovs'kyy psykhoterapevtychnyy zhurnal, vol.2.

14. Esselson, S. B. and Letunovsky, V.V. "Existentialism in psychology", Existential tradition: philosophy., Psychology, psychotherapy [Online], available at: http://hpsy.ru/ public / x2711.htm.

15. Yalom, Irvin D. (2008), "Staring at the Sun: Overcoming the Terror of Death", JOSSEY-BASS A Wiley Imprint.

16. Skarlosh, S. (2012), "How to learn to love. Irvine Yalom about neuroses, the meaning of life, his mother and the Almighty", Rosiys'kyy Reporter, vol. 45 (274).

17. Yalom, Irvin D. (2008), "Existential Psychotherapy”, Kindle, Aug.1. 